DOI: $10.17805 /$ trudy.2019.1.13

\title{
НОВЕЙШАЯ ИСТОРИЯ РОССИЙСКОЙ ПСИХОЛОГИИ ПО СТРАНИЦАМ ЖУРНАЛА «МЕТОДОЛОГИЯ И ИСТОРИЯ ПСИХОЛОГИИ» (2006-2018 ГГ.)
}

\author{
И. Н. Карицкий
}

Московский институт психоанализа; Российский государственный университет им. А. Н. Косыгина

Аннотация: Рассмотрены, проанализированы и классифицированы работы по истории психологии, опубликованные в журнале «Методология и история психологии» за 2006-2018 годы. Отдельно выделены статьи историко-методологической направленности, развитию школ в психологии, публикации по истории психологии во время Второй мировой и Великой отечественной войн, персоналии, работы по генезису психологических понятий, концепций и методов, статьи по психоанализу, древней психологии и другие.

По материалам научного доклада на конференции «Кросс-культурные и междисциплинарные исследования в истории психологии: результаты и перспективы» (Москва, 24-25 ноября 2018 г.), проведенной в рамках проекта № 18-513-18017, поддержанного РФФИ.

Ключевые слова: история психологии; методология истории психологии; «Методология и история психологии»; история российской психологии

\section{RECENT HISTORY OF RUSSIAN PSYCHOLOGY ON THE PAGES OF THE JOURNAL “METHODOLOGY AND HISTORY OF PSYCHOLOGY” (2006-2018)}

\author{
I. N. Karitskiy \\ Moscow Institute of Psychoanalysis; Kosygin Russian State University
}

Abstract: The paper considers, analyses, and classifies scientific works on the history of psychology published in the journal "Methodology and History of Psychology" in 2006-2018. Special attention is paid to the articles devoted to history and methodology, the development of schools of psychology; publications on the history of psychology during the Second World War and the Great Patriotic War; personaliae; works on the genesis of psychological notions, concepts, and methods; articles on psychoanalysis, ancient psychology, etc.

The research is based on the materials of the scientific report at the conference "CrossCultural and Interdisciplinary Studies into the History of Psychology: Results and Prospects" (Moscow, 24-25 November 2018), held within the project No. 18-513-18017 supported by RFBR.

Keywords: history of psychology; methodology of the history of psychology; "Methodology and History of Psychology"; history of Russian psychology 
Журнал «Методология и история психологии» - один из немногих узконаправленных российских научных журналов, специализирующийся на истории психологии, печатный орган историков психологии. Хотя журнал недавно возобновил свое издание после многолетнего перерыва, в нем за весь период издания было опубликовано более ста тридцати статей по истории психологии различной направленности: от исследований древнеиндийских и древнекитайских представлений о психике, «Психологии» $\mathrm{P}$. Гоклениуса до современных обзоров по истории психологии, от работ историко-описательного характера до историко-методологических исследований. Также многообразен круг авторов по странам, городам, организациям, научным интересам, историко-методологическим позициям. Например, на историко-психологические темы в журнале помимо российских исследователей опубликованы работы авторов из Великобритании, Беларуси, Болгарии, Германии, Дании, Израиля, Казахстана, Канады, Латвии, США, Украины.

Вопросы методологии истории психологии обсуждаются в обзорной статье В.А. Кольцовой и Ю. Н. Олейника «История отечественной и мировой психологической мысли: постигая прошлое, понимать настоящее, предвидеть будущее» (Кольцова, Олейник, 2006), в аналитических исследованиях Т. Д. Марцинковской «Проблемы истории психологии в трудах Г. Г. Шпета» (Марцинковская, 2007), В. И. Олешкевича «История психологии как история психотехники» (Олешкевич, 2007), В. В. Умрихина «Историко-методологические проблемы анализа научных школ в психологии» (Умрихин, 2007), Ю. Н. Олейника «Периодизация истории психологии: проблемы и перспективы» (Олейник, 2008), К. Э. Мартинсоне и А. К. Карповой «Интерпретация психологии в социокультурных взаимосвязях» (Мартинсоне, Карпова, 2008), С. А. Богданчикова «Современные отечественные авторы о научных школах в советской психологии 1920-1930 гг.» (Богданчиков, 2009), В. А. Мазилова и Ю. Н. Слепко «История психологии в контексте истории гуманитарного знания» (Мазилов, Слепко, 2009), М. С. Гусельцевой «Психология и история: культурно-психологическая эпистемология» (Гусельцева, 2010), В. Ф. Петренко «Конструирование истории» (Петренко, 2018) и др.

Так, В. А. Кольцова отмечает, «что интерес к историко-психологическим исследованиям возникает в наиболее сложные периоды развития отечественного психологического знания» (Кольцова, Олейник, 2006: 152). Как известно, вопросы методологии истории психологии подробно исследованы В. А. Кольцовой в монографии «Теоретико-методологические основы истории психологии» (Кольцова, 2004). В то же время Ю. Н. Олейник обозначил основные ключевые методологические проблемы современной истории психологии, находящиеся «в центре внимания историков психологии и на периферии их интересов» (Кольцова, Олейник, 2006: 152). Как наибо- 
Научные труды Московского гуманитарного университета 2019 № 1

лее значимая им была освещена «проблема теоретико-методологических оснований историко-психологических исследований в контексте происходящих в современной науке изменений в понимании обоснованности результатов научных разработок» (там же: 152-153). Среди таких изменений Ю. Н. Олейник «выделил отказ от догматов неопозитивизма, формирование новых критериев научности, ориентированных не только на рационализм, интеграция научных и вненаучных идей в едином знании о человеке и его внутреннем мире» (там же: 153).

В другом исследовании Ю. Н. Олейник указывает, что «одной из важных методологических проблем современной истории психологии является проблема периодизации развития психологического знания в целом и психологической науки в частности» (Олейник, 2008: 25). Согласно автору, основная цель периодизации заключается «в выделении в едином процессе развития психологических знаний отдельных качественно отличающихся друг от друга периодов, в соответствии с объективными закономерностями или определенными признаками, характеризующими коренные изменения и поворотные моменты этого развития, а также обобщение всего многообразия исторических фактов, характеризующих процесс развития психологии в общей исторической перспективе» (там же). В качестве критериев периодизации истории психологии Ю. Н. Олейник предлагает использовать концепцию типов научной рациональности и структуры оснований науки B. С. Степина (там же: 30-31).

В. В. Умрихин рассматривает историко-методологические проблемы, обусловленные «исторической реконструкцией научных школ в психологии». Автором «проводится анализ понятия “научная школа”, описываются типы научных школ, среди которых особо выделяется школа - исследовательский коллектив, раскрывается роль исследовательской программы как консолидирующего начала научной школы. С этих позиций обсуждаются основные методологические принципы историко-научной реконструкции школ в психологии», выделяются «главные черты, которые характеризуют школу - исследовательский коллектив» (Умрихин, 2007: 5, 7, 9-10). Историю школ в психологии также рассматривают многие другие исследователи: Б. Д. Парыгин (Парыгин, 2007), С. А. Богданчиков (Богданчиков, 2009), О. Г. Носкова (Носкова, 2006), М. И. Турецкий (Турецкий, 2006, 2007, $2008,2009,2010)$, Е. В. Левченко (Левченко, 2006), А. Н. Ждан (Ждан, 2006), В. Ф. Петренко (Петренко, 2018), Е. Е. Соколова (Соколова, 2007), В. Г. Морогин (Морогин, 2008), С. А. Векилова (Векилова, 2008), Н. А. Логинова (Логинова, 2008), Д. Д. Дуйсенбеков (Дуйсенбеков, 2009), Е. А. Володарская (Володарская, 2009), Э. В. Тихонова (Тихонов, 2010), Х. Люк (Люк, Волкова, 2011), И. Н. Семенов (Семенов, 2018) и др. 
Ряд методологических и историко-методологических проблем обсуждается в серии публикаций А. Н. Ждан «Развитие взглядов на предмет психологии» (Ждан, 2006), «Методологические уроки С. Л. Рубинштейна» (Ждан, 2007), «Проблема объяснения в психологии: исторический аспект» (Ждан, 2008), «Пути и принципы исследования сознания в истории психологии» (Ждан, 2009), «Масштабность личности и деятельности А.Н. Леонтьева» (Ждан, 2018). Так, А. Н. Ждан пишет, что «вопрос о предмете становится особенно важным в некоторые периоды, когда возникают новые области науки, из которых психология пытается заимствовать свои объяснительные принципы и схемы» (Ждан, 2006: 8), отмечая роль в формировании предмета психологии эволюционной концепции Ч. Дарвина, социологии Э. Дюркгейма, общей теории систем, нейрофизиологии и других наук. Автор особо подчеркивает, что «принцип историзма требует рассматривать все сложившиеся к настоящему времени определения предмета психологии как важные, исторически обусловленные и потому необходимые шаги на пути развития психологической науки. Изучение истории подводит к выводу о том, что не может быть окончательного решения о предмете психологии» (Ждан, 2006: 21). А. Н. Ждан в своих публикациях делает и ряд других важных методологических утверждений.

В публикациях В. А. Мазилова на страницах журнала «Методология и история психологии» обсуждается широкий спектр методологических, историко-методологических и историко-психологических вопросов. Вот только некоторые из них: «О становлении психологии как самостоятельной науки» (Мазилов, 2007b, 2008a), «Становление метода психологии: страницы истории (метод интроспекции)» (Мазилов, 2007a), «Михаил Семенович Роговин - методолог психологии» (Мазилов, 2006b), «Предвестник психологии нового века: о методологическом значении исследований А. Г. Маслоу» (Мазилов, 2008b), «Б. Г. Ананьев и методологические вопросы психологии» (Мазилов, 2008c), «История психологии в контексте истории гуманитарного знания» (Мазилов, Слепко, 2009). В. А. Мазилов замечает: «...в истории психологии накопилось значительное количество мифов, неадекватных оценок, исторических аберраций, которые, с одной стороны, препятствуют дальнейшей разработке истории психологии, а с другой затрудняют понимание логики развития психологической науки, что совершенно необходимо для определения тенденций ее развития» (Мазилов, 2007: 5). Аргументировано критикуя ряд методологических мифов истории психологии, автор утверждает, что «научная психология была конституирована методом самонаблюдения» и является прямой наследницей вундтовской психологии (Мазилов, 2008а: 7).

Вопросы методологии историко-психологических исследований явля- 
Научные труды Московского гуманитарного университета

2019 № 1

ются предметом постоянного внимания С. А. Богданчикова. В таких статьях, как «Основные направления и течения в отечественной психологии 1920-х годов» (Богданчиков, 2006), «От Л. С. Выготского к Г. И. Челпанову и обратно» (Богданчиков, 2007), «Сквозь время: школа Г. И. Челпанова в ее развитии, основных чертах и историческом значении» (Богданчиков, 2008а), «К вопросу о персональном составе школы С.Л. Рубинштейна» (Богданчиков, 2008b), «Современные отечественные авторы о научных школах в советской психологии 1920-1930 гг.» (Богданчиков, 2009), «Проблема генезиса советской психологии» (Богданчиков, 2018).

С. А. Богданчиков исследует проблему предпосылок, формирования и развития советской психологии, ее основные направления, школы и методологические принципы. В то же время, автор заключает: «...проведенный анализ показал, что в настоящее время отсутствует ясный и убедительный ответ на вопрос о научных школах в советской психологии 1920-1930-х гг. С нашей точки зрения, это является прямым следствием идеологически обусловленного, вытекающего из общенаучных требований и традиций советских времен невнимания исследователей, работающих в области истории советской психологии, к проблеме научных школ вообще и понятию "научная школа" - в частности» (Богданчиков, 2009: 29).

В ряде публикаций в той или иной степени представлена тема развития психологии во время Второй мировой и Великой отечественной войн. Эта тематика отражена в таких работах, как Н. Ю. Масоликова, М. Ю. Сорокина «История российского научного зарубежья и психологическое сообщество» (Масоликова, Сорокин, 2011), Х. Люк, М. В. Волкова «Тамара Дембо: научный портрет на фоне XX века» (Люк, Волкова, 2011), О. Г. Носкова «Московская школа индустриальной психотехники» (Носкова, 2006), Н. В. Золотовой «Научное наследие и жизненный путь Б. В. Зейгарник» (Золотова, 2007), С. А. Богданчиков «К вопросу о персональном составе школы С. Л. Рубинштейна» (Богданчиков, 2008b), А. Г. Лидерс «Развитие представлений об ориентировке и ориентировочной деятельности в истории отечественной психологии» (Лидерс, 2006), Н. Ю. Стоюхиной «Судьба и научное творчество Серафима Михайловича Василейского» (Стоюхина, 2010), А. Н. Ждан «Масштабность личности и деятельности А.Н. Леонтьева» (Ждан, 2018) и в др.

В частности, в статье Х. Люка и М. В. Волковой «Тамара Дембо: научный портрет на фоне XX века» отражен период работы Т. Дембо в области «социально-психологической реабилитации людей, ставших инвалидами на фронтах Второй мировой войны», реабилитационной психологией она занималась до конца жизни (Люк, Волкова, 2011). В публикации Н. В. Золотовой «Научное наследие и жизненный путь Б. В. Зейгарник» освещен период работы Б. В. Зейгарник в Восстановительном госпитале в городе Кисегач на 
Урале под руководством А. Р. Лурии, где происходило лечение и восстановление тяжелораненых бойцов; там она «проводила патопсихологические исследования больных с реактивной постконтузионной глухотой»; а затем показан период работы с 1943 г. «в ЦНИИ психиатрии в должности заведующей патопсихологической лабораторией» (Золотова, 2007: 139-140).

В журнале «Методология и история психологии» имеется значительное число персоналий. В частности, имеются статьи, посвященные И. Н. Шпильрейну и С. Г. Геллерштейну (Носкова, 2006), И. И. Лапшину (Большакова, 2006; 2008; Тихонова, 2010), А. И. Галичу (Лариков, 2006), М. С. Роговину (Залевский, 2006; Мазилов, 2006b), 3. Фрейду (Турецкий, 2006), М. М. Бахтину (Кучинский, 2007), Я. Л. Морено (Золотовицкий, 2007), А. Адлеру (Турецкий, 2007; Олешкевич, 2009а; 2010), С. Л. Рубинштейну (Ждан, 2007), Г. И. Челпанову (Богданчиков, 2008а), М. И. Каринскому (Сердюкова, 2008), К. Г. Юнгу (Турецкий, 2008; 2009; 2010), К. Ясперсу (Акопов, 2008), А. Г. Маслоу (Мазилов, 2008b), М. Я. Басову (Левченко, 2008), Б. Г. Ананьеву (Логинова, 2008), Л. М. Веккеру (Осорина, 2008), М. М. Муканову (Дуйсенбеков, 2009), В. Н. Пушкину (Шавырина, 2009), А. Бергсону (Акопов, 2009), О.К. Тихомирову (Бабаева и др., 2009), М. И. Владиславлеву (Тихонова, 2010:), С.М. Василейскому (Стоюхина, 2010), А.Н. Леонтьеву (Ждан, 2018), А. В. Брушлинскому (Знаков, Сергиенко, 2018) и др.

Несколько статей посвящено развитию психологии в других странах: Н. Димитрова «Основные моменты развития психологии в Болгарии в первой половине XX века» (Болгария) (Димитрова, 2010), Х. Люк «Групповые процессы в научных исследованиях (на примере “Топологической группы” Курта Левина») (США) (Люк, 2010), Х. Люк, М. Роте «Общая психология область науки без истории?» (Германия) (Люк, Роте, 2018) и др.

Ряд статей раскрывают содержание психологических понятий, концепций и методов в их генезисе и ретроспективе психологических представлений. Это, например, публикации А. Н. Ждан «Развитие взглядов на предмет психологии» (Ждан, 2006), «Проблема объяснения в психологии: исторический аспект» (Ждан, 2008), «Пути и принципы исследования сознания в истории психологии» (Ждан, 2009); В. А. Мазилова «О предмете психологии» (Мазилов, 2006а), «Становление метода психологии: страницы истории (метод интроспекции)» (Мазилова, 2007a); А. А. Пископпеля «Педология и психотехника: исторический опыт методологического оформления и обоснования комплексных научно-технических дисциплин» (Пископпель, 2006; 2007), В. К. Шабельникова «Предметность и субъектность детерминирующего мира в концепциях психологии» (Щабельникова, 2006); А. Г. Лидерса «Развитие представлений об ориентировке и ориентировочной деятельности в истории отечественной психологии» (Лидерс, 2006); 
Научные труды Московского гуманитарного университета 2019 № 1

А. М. Улановского «Феноменологический метод в психологии, психиатрии и психотерапии» (Улановский, 2007); «История и векторы развития качественных исследований в психологии» (Улановский, 2008); А. Г. Чесноковой «Детерминизм, историзм и принцип восхождения от абстрактного к конкретному в психологической теории С. Л. Рубинштейна» (Чеснокова, 2007); А. С. Арсеньева «От субъекта к личности (Полемика о творческой судьбе С. Л. Рубинштейна) (Арсеньев, 2007; 2008); Н. Ф. Талызиной «Сущность деятельностного подхода в психологии» (Талызина, 2007); С. П. Сенющенкова «0 понятии “внутренняя деятельность" в теории А. Н.Леонтьева (Сенющенков, 2007); Н. Ю. Федуниной «Представления о сознании в ранних трудах Пьера Жане» (Федунина, 2009); И. Е. Сироткиной «Из истории одной психологической категории: музыкальные аффекты, чувства, эмоции» (Сироткина, 2009); И. Н. Карицкого «Понятие субъекта и объекта в философии и психологии» (Карицкий, 2010), «Конструирование миров» (Карицкий, 2018); Е. В. Косиловой «Субъект: от философии и психологии до психопатологии и эзотеризма» (Косилова, 2010); В. В. Умрихина и А. Н. Ромащука «Функциональный подход как неявное основание становления психологии ХХ века» (Умрихин, Ромащук, 2010); В. Ф. Петренко «Конструирование истории» (Петренко, 2018); Х. Люка и М. Роте «Общая психология - область науки без истории?» (Люк, Роте, 2018) и многие другие.

В журнале имеется значительный ряд статей по психоанализу. Серия статей М. И. Турецкого: «Шломо Зигмунд Фрейд» (Турецкий, 2006), «Орел из пригорода (к 70-летию со дня смерти А. Адлера)» (Турецкий, 2007), «Строитель Боллингенской башни» (о К. Г. Юнге) (Турецкий, 2008; 2009; 2010). А также статьи Е. В. Левченко «Психоанализ и психологическое знание: динамика отображений психоанализа в отечественных учебниках психологии» (Левченко, 2006), Е. А. Белан «Психология активности в учении о человеке Эриха Фромма» (Белан, 2008), В. И. Олешкевича «История психологии как история психотехники» (Олешкевич, 2007), «Истоки и пути формирования психологии А. Адлера» (Олешкевич, 2009а), «К проблеме социологии психоаналитического знания» (Олешкевич, 2009b), «Поздний Адлер, или Пути развития индивидуальной психологии» (Олешкевич, 2010). История психоанализа представлена также в статьях Б. Д. Парыгина «История отечественной социальной психологии» (Парыгин, 2007), С. А. Богданчикова «Основные направления и течения в отечественной психологии 1920-х годов» (Богданчиков, 2006), В. А. Бажанова «Первый учитель А. Р. Лурии: Н. А. Васильев как психолог» (Бажанов, 2008), Н. С. Бурлаковой и В. И. Олешкевича «Идентичность и проблема субъекта в современной психологии» (Бурлакова, Олешкевич, 2010), Е. В. Косиловой «Субъект: от философии и психологии до психопатологии и эзотеризма» (Косилова, 2010) и др. 
Отдельно необходимо отметить публикации В. Е. Еремеева о психологических представлениях в Древнем Китае и Древней Индии: «Древнекитайское учение о структуре психики» (Еремеев, 2006), «Представления о структуре психики в древнеиндийском учении санкхья» (Еремеев, 2008). А также новый перевод работы С. Кьеркегора «Утрата свободы в сфере духа» (1844/2011) с комментариями переводчика А.В. Лызлова и впервые переведенный с латинского языка трактат редактора-составителя Р. Гоклениуса «ЧҮХОАОГІА: то есть о совершенстве человека, о духе и, в первую очередь, о возникновении его в рассуждениях и спорах некоторых богословов и философов нашего века...» (Гоклениус, 2018), выполненный Л. И. Рагозиным с его же обширными комментариями во вводной статье (Рагозин, 2018).

Естественно, в этом кратком обзоре невозможно охватить содержание всех историко-психологических статей, опубликованных в журнале «Методология и история психологии» за 2006-2018 годы, тем более что и в сугубо методологических статьях рассматриваются вопросы истории психологии. В то же время и представленный обзор дает представление о многообразии направлений и качестве исследований в этой области.

\section{СПИСОК ЛИТЕРАТУРЫ}

Акопов, Г. В. (2008) Исследовательский агностицизм и объяснительная провидентность (к 125-летию со дня рождения К. Ясперса) // Методология и история психологии. Вып. 2. С. 147-154.

Акопов, Г. В. (2009) 150 лет со дня рождения Анри Бергсона // Методология и история психологии. Вып. 3. С. 131-135.

Арсеньев, А. С. (2007) От субъекта к личности (Полемика о творческой судьбе С.Л. Рубинштейна). Ч. І. // Методология и история психологии. Вып. 4. С. 99-137.

Арсеньев, А. С. (2008) От субъекта к личности (Полемика о творческой судьбе С.Л. Рубинштейна). Ч. II // Методология и история психологии. Вып. 4. С. 109-158.

Бабаева, Ю. Д. и др. (2009) О вкладе О. К. Тихомирова в методологию, теорию и экспериментальную практику психологической науки // Методология и история психологии. Вып. 4. С. 9-27.

Бажанов, В. А. (2008) Первый учитель А. Р. Лурии: Н. А. Васильев как психолог // Методология и история психологии. Вып. 2. С. 69-78.

Белан, Е. А. (2008) Психология активности в учении о человеке Эриха Фромма // Методология и история психологии. Вып. 2. С. 121-128.

Богданчиков, С. А. (2006) Основные направления и течения в отечественной психологии 1920-х годов // Методология и история психологии. Вып. 2. С. 21-30. 
Богданчиков, С. А. (2007) От Л. С. Выготского к Г. И. Челпанову и обратно // Методология и история психологии. Вып. 2. С. 68-78.

Богданчиков, С. А. (2008а) Сквозь время: школа Г. И. Челпанова в ее развитии, основных чертах и историческом значении // Методология и история психологии. Вып. 2. С. 33-50.

Богданчиков, С. А. (2008b) К вопросу о персональном составе школы С. Л. Рубинштейна // Методология и история психологии. Вып. 2. С. 159-179.

Богданчиков, С. А. (2009) Современные отечественные авторы о научных школах в советской психологии 1920-1930 гг. (опыт детального критического анализа) // Методология и история психологии. Вып. 2. С. 7-31.

Богданчиков С. А. (2018). Проблема генезиса советской психологии (юбилейные размышления) // Методология и история психологии. Вып. 1. C. 229-232.

Большакова, В. В. (2006) И. И. Лапшин о психологии мистического познания и «вселенского чувства» // Методология и история психологии. Вып. 2. С. 82-93.

Большакова, В. В. (2008) И. И. Лапшин о психологических основах творческой деятельности личности // Методология и история психологии. Вып. 2. С. 60-68.

Бурлакова, Н. С., Олешкевич, В. И. (2010) Идентичность и проблема субъекта в современной психологии // Методология и история психологии. Вып. 1. С. 156-183.

Векилова, С. А. (2008) Исторические корни школ в советской психологии // Методология и история психологии. Вып. 2. С. 51-59.

Володарская, Е. А. (2009) Науковедческий анализ научной школы О. К. Тихомирова // Методология и история психологии. Вып. 4. С. 28-44.

Гоклениус, Р. (2018) ЧҮХОАОГІА: то есть о совершенстве человека, о духе и, в первую очередь, о возникновении его в рассуждениях и спорах некоторых богословов и философов нашего века... // Методология и история психологии. Вып.2. С. 143-149.

Гусельцева, М. С. (2010) Психология и история: культурно-психологическая эпистемология // Методология и история психологии. Вып. 2. С. 7-22.

Димитрова, Н. (2010) Основные моменты развития психологии в Болгарии в первой половине XX века // Методология и история психологии. Вып. 2. С. 49-56.

Дуйсенбеков, Д. Д. (2009) М. М. Муканов как основатель казахстанской психологической школы // Методология и история психологии. Вып. 2. С. $160-167$.

Еремеев, В. Е. (2006) Древнекитайское учение о структуре психики // Методология и история психологии. Вып. 2. С. 138-150. 
Еремеев, В. Е. (2008) Представления о структуре психики в древнеиндийском учении санкхья // Методология и история психологии. Вып. 2. C. $162-174$.

Ждан, А. Н. (2006) Развитие взглядов на предмет психологии // Методология и история психологии. Вып. 1. С. 8-22.

Ждан, А. Н. (2007) Методологические уроки С.Л. Рубинштейна // Методология и история психологии. Вып. 4. С. 69-82.

Ждан, А. Н. (2008) Проблема объяснения в психологии: исторический аспект // Методология и история психологии. Вып. 1. С. 22-27.

Ждан, А. Н. (2009) Пути и принципы исследования сознания в истории психологии // Методология и история психологии. Вып. 1. С. 47-60.

Ждан, А. Н. (2018) Масштабность личности и деятельности А. Н. Леонтьева // Методология и история психологии. Вып. 1. С. 186-206.

Залевский, Г. В. (2006) О научном наследии М. С. Роговина // Методология и история психологии. Вып. 2. С. 99-102.

Знаков, В. В., Сергиенко, Е. А. (2018) Андрей Владимирович Брушлинский: жизнь, отданная науке // Методология и история психологии. Вып. 2. C. 5-21.

Золотова, Н. В. (2007) Научное наследие и жизненный путь Б. В. Зейгарник // Методология и история психологии. Вып. 2. С. 135-146.

Золотовицкий, Р. А. (2007) Социометрия Я. Л. Морено // Методология и история психологии. Вып. 2. С. 107-121.

Карицкий, И. Н. (2010) Понятие субъекта и объекта в философии и психологии // Методология и история психологии. Вып. 1. С. 69-101.

Карицкий, И. Н. (2018) Конструирование миров // Методология и история психологии. Вып. 1. С. 5-14.

Кольцова, В. А. (2004) Теоретико-методологические основы истории психологии. М. : Институт психологии РАН.

Кольцова, В. А., Олейник, Ю. Н. (2006) История отечественной и мировой психологической мысли: постигая прошлое, понимать настоящее, предвидеть будущее // Методология и история психологии. Вып. 2. С. 151-159.

Косилова, Е. В. (2010) Субъект: от философии и психологии до психопатологии и эзотеризма // Методология и история психологии. Вып. 1. С. 102-121.

Кучинский, Г. М. (2007) М.М. Бахтин и феноменологический метод исследования личности // Методология и история психологии. Вып. 1. С. 151-163.

Лариков, А. В. (2006) Психологические воззрения А.И. Галича в применении к судебной практике российской юриспруденции XIX века // Методология и история психологии. Вып. 2. С. 94-98.

Левченко, Е. В. (2006) Психоанализ и психологическое знание: динамика отображений психоанализа в отечественных учебниках психологии // 
Методология и история психологии. Вып. 2. С. 128-137.

Левченко, Е. В. (2008) Михаил Яковлевич Басов: жизненный путь и психологическая концепция // Методология и история психологии. Вып. 4. С. 21-45.

Лидерс, А. Г. (2006) Развитие представлений об ориентировке и ориентировочной деятельности в истории отечественной психологии // Методология и история психологии. Вып. 2. С. 57-66.

Логинова, Н. А. (2008) Б. Г. Ананьев - основатель Ленинградской психологической школы // Методология и история психологии. Вып. 4. С. 46-58.

Люк, Х. (2010) Групповые процессы в научных исследованиях (на примере «Топологической группы» Курта Левина) // Методология и история психологии. Вып. 3. С. 77-89.

Люк, Х., Волкова, М. В. (2011) Тамара Дембо: научный портрет на фоне XX века // Методология и история психологии. Вып. 2. С. 40-73.

Люк, Х. Э., Роте, М. (2018) Общая психология - область науки без истории? // Методология и история психологии. Вып. 2. С. 113-129.

Мазилов В.А. (2006а) О предмете психологии // Методология и история психологии. Вып. 1. С. 55-72.

Мазилов, В. А. (2006b) Михаил Семенович Роговин - методолог психологии // Методология и история психологии. Вып. 2. С. 103-112.

Мазилов, В. А. (2007а) Становление метода психологии: страницы истории (метод интроспекции) // Методология и история психологии. Вып. 1. С. 61-85.

Мазилов, В. А. (2007b) О становлении психологии как самостоятельной науки. Ч. 1 // Методология и история психологии. Вып. 2. С. 3-20.

Мазилов, В. А. (2008а) О становлении психологии как самостоятельной науки. Ч. 2 // Методология и история психологии. Вып. 2. С. 7-24.

Мазилов, В. А. (2008b) Предвестник психологии нового века: о методологическом значении исследований А.Г. Маслоу // Методология и история психологии. Вып. 2. С. 155-161.

Мазилов, В. А. (2008c) Б. Г. Ананьев и методологические вопросы психологии // Методология и история психологии. Вып. 4. С. 59-69.

Мазилов, В. А., Слепко, Ю. Н. (2009) История психологии в контексте истории гуманитарного знания (Рецензия на книги Роджера Смита) // Методология и история психологии. Вып. 2. С. 178-186.

Мартинсоне, К. Э., Карпова, А. К. (2008) Интерпретация психологии в социокультурных взаимосвязях // Методология и история психологии. Вып. 1. С. 28-40.

Марцинковская, Т. Д. (2007) Проблемы истории психологии в трудах Г. Г. Шпета // Методология и история психологии. Вып. 2. С. 21-31. 
Масоликова, Н. Ю., Сорокина, М. Ю. (2011) История российского научного зарубежья и психологическое сообщество // Методология и история психологии. Вып. 2. С. 92-109.

Морогин, В. Г. (2008) Классика эмпирических исследований в европейской психологии второй половины XIX столетия // Методология и история психологии. Вып. 2. С. 91-107.

Носкова, О. Г. (2006) Московская школа индустриальной психотехники // Методология и история психологии. Вып. 2. С. 31-46.

Олейник, Ю. Н. (2008) Периодизация истории психологии: проблемы и перспективы // Методология и история психологии. Вып. 2. С. 25-32.

Олешкевич, В. И. (2007) История психологии как история психотехники // Методология и история психологии. Вып. 2. С. 32-39.

Олешкевич, В. И. (2009а) Истоки и пути формирования психологии А. Адлера // Методология и история психологии. Вып. 2. С. 104-123.

Олешкевич, В. И. (2009b) К проблеме социологии психоаналитического знания // Методология и история психологии. Вып. 3. С. 90-95.

Олешкевич, В. И. (2010) Поздний Адлер, или Пути развития индивидуальной психологии // Методология и история психологии. Вып. 2. С. 65-76.

Осорина, М. В. (2008) Научное творчество и судьба Льва Марковича Веккера (к 90-летию со дня рождения) // Методология и история психологии. Вып. 4. С. 85-100.

Парыгин, Б. Д. (2007) История отечественной социальной психологии // Методология и история психологии. Вып. 2. С. 40-53.

Петренко, В. Ф. (2018) Конструирование истории // Методология и история психологии. Вып. 1. С. 15-33.

Пископпель, А. А. (2006) Педология и психотехника: исторический опыт методологического оформления и обоснования комплексных научно-технических дисциплин. Ч. 1. // Методология и история психологии. Вып. 2. С. $47-56$.

Пископпель, А. А. (2007) Педология и психотехника: исторический опыт методологического оформления и обоснования комплексных научно-технических дисциплин. Ч. 2. // Методология и история психологии. Вып. 2. C. 94-106.

Рагозин, Л. И. (2018) Наука о разумной душе - от слова к книге. Введение к переводу трактата «ЧҮХО АОГІА» // Методология и история психологии. Вып. 2. С. 130-142.

Семенов, И. Н. (2018) История и логика развития в России «Общества психологов» // Методология и история психологии. Вып. 2. С. 89-112.

Сенющенков, С. П. (2007) О понятии «внутренняя деятельность» в теории А. Н. Леонтьева // Методология и история психологии. Вып. 4. С. 179-192. 
Сердюкова, Ю. А. (2008) Психологические взгляды М. И. Каринского // Методология и история психологии. Вып. 2. С. 79-90.

Сироткина, И. Е. (2009) Из истории одной психологической категории: музыкальные аффекты, чувства, эмоции // Методология и история психологии. Вып. 2. С. 146-159.

Соколова, Е. Е. (2007) К проблеме методологии построения общепсихологической теории в школе А. Н. Леонтьева // Методология и история психологии. Вып. 4. С. 163-178.

Стоюхина, Н. Ю. (2010) Судьба и научное творчество Серафима Михайловича Василейского // Методология и история психологии. Вып. 2. С. 115-131.

Талызина, Н. Ф. (2007) Сущность деятельностного подхода в психологии // Методология и история психологии. Вып. 4. С. 157-162.

Тихонова, Э. В. (2010) У истоков создания школы философской психологии в Санкт-Петербургском университете: Михаил Иванович Владиславлев // Методология и история психологии. Вып. 2. С. 100-114.

Турецкий, М. И. (2006) Шломо Зигмунд Фрейд // Методология и история психологии. Вып. 2. С. 113-127.

Турецкий, М. И. (2007) Орел из пригорода (к 70-летию со дня смерти А. Адлера) // Методология и история психологии. Вып. 2. С. 122-134.

Турецкий, М. И. (2008) Строитель Боллингенской башни. Ч. 1 // Методология и история психологии. Вып. 2. С. 108-120.

Турецкий, М. И. (2009) Строитель Боллингенской башни. Ч. 2 // Методология и история психологии. Вып. 2. С. 124-145.

Турецкий, М. И. (2010) Строитель Боллингенской башни. Ч. 3 // Методология и история психологии. Вып. 2. С. 77-99.

Улановский, А. М. (2007) Феноменологический метод в психологии, психиатрии и психотерапии // Методология и история психологии. Вып. 1. С. $130-150$.

Улановский, А. М. (2008) История и векторы развития качественных исследований в психологии // Методология и история психологии. Вып. 2. С. $129-139$.

Умрихин, В. В. (2007) Историко-методологические проблемы анализа научных школ в психологии // Методология и история психологии. Вып. 4. C. 5-14.

Умрихин, В. В., Ромащук, А. Н. (2010) Функциональный подход как неявное основание становления психологии XX века // Методология и история психологии. Вып. 3. С. 26-37.

Федунина, Н. Ю. (2009) Представления о сознании в ранних трудах Пьера Жане // Методология и история психологии. Вып. 2. С. 96-103.

Чеснокова, А. Г. (2007) Детерминизм, историзм и принцип восхождения 
от абстрактного к конкретному в психологической теории С. Л. Рубинштейна // Методология и история психологии. Вып. 4. С. 83-98.

Шабельников, В. К. (2006) Предметность и субъектность детерминирующего мира в концепциях психологии // Методология и история психологии. Вып. 1. С. 23-40.

Шавырина, Г. В. (2009) В. Н. Пушкин. Жизнь, отданная науке // Методология и история психологии. Вып. 2. С. 168-177.

Дата поступления: 15.01.2019 2.

Карицкий Игорь Николаевич - кандидат психологических наук, главный специалист Информационно-технического отдела Московского института психоанализа; доцент кафедры психологии Российского государственного университета имени А. Н. Косыгина. Адрес: 121170, Россия, г. Москва, Кутузовский проспект, д.34, стр.14. Тел.: +7 (910) 476-96-14. Эл. адрес: ignikkar@mail.ru

Karitsky Igor Nikolaevich, Candidate of Psychology, Chief Specialist, Information Technology Department, Moscow Institute of Psychoanalysis, Associate Professor, Department of Psychology, Kosygin Russian State University. Postal address: 34, Bldg. 14, Kutuzovsky Ave., Moscow, Russian Federation, 121170. Tel.: +7 (910) 476-96-14. E-mail: ignikkar@mail.ru

\section{Для цитирования:}

Карицкий И. Н. Новейшая история российской психологии по страницам журнала «Методология и история психологии» (2006-2018 гг.) [Электронный ресурс] // Научные труды Московского гуманитарного университета. 2019. № 1. URL: http://journals.mosgu. ru/trudy/article/view/940 (дата обращения: дд.мм.гг.). DOI: 10.17805/trudy.2019.1.13 